\title{
PENGARUH EFEKTIVITAS PEMERIKSAAN PAJAK DAN EFEKTIVITAS PENAGIHAN PAJAK DENGAN SURAT PAKSA TERHADAP PENERIMAAN PAJAK PADA KANTOR PELAYANAN PAJAK PRATAMA BATAM UTARA
}

\author{
Lobinsen $^{1}$, Vargo Christian L. Tobing ${ }^{2}$ \\ ${ }^{1}$ Alumni Universitas Putera Batam \\ ${ }^{2}$ Dosen Universitas Putera Batam \\ email: robi17sen0511@gmail.com
}

\begin{abstract}
The purpose of this study to determine the effectiveness of tax audits and effectiveness of tax collection by forced letter towards tax revenue. The object from the purpose of this study is tax service office batam north. The method used is quantitative descriptive. Data collection techniques in this study using boring sampling that sampling techinuque is retrieve all data from the existing population. In this study, the result of detailed examination that the effectiveness of tax audits is partially significant towards tax revenue, where the $t$ count 17,429 > t table 2015 or with the significant level of $t$ count 0,003 $<0,05$. In this study, the result of detailed examination that the effectiveness of tax collection by forced letter also partially significant towards tax revenue, where the t count 11,404 > t table 2015 or with the significant level of $t$ count 0,008 $<0,05$. The result of The effectiveness of tax audits and effectiveness of tax collection by forced letter simultaneously towards tax revenue at tax service office batam north, where $f$ count 387,645 > f table 5,786 with significant level of $f$ count 0,003 <0,05.
\end{abstract}

Keywords: effectiveness of tax audits, effectiveness of tax collection by forced letter and tax revenue

\section{PENDAHULUAN}

Pajak merupakan salah satu sumber penerimaan negara yang sangat penting dan bersifat strategis karena mempunyai pengaruh yang besar terhadap pembangunan nasional. Negara Republik Indonesia adalah negara hukum berdasarkan Pancasila dan Undang-Undang Dasar 1945, yang bertujuan untuk mewujudkan tata kehidupan negara dan bangsa yang adil dan sejahtera, aman, dan tertib, serta menjamin kedudukan hukum yang sama bagi warga masyarakat. Untuk mencapai tujuan tersebut, pembangunan nasional yang dilaksanakan secara berkesinambungan dan berkelanjutan serta merata di seluruh tanah air memerlukan biaya besar yang harus digali dari sumber kemampuan sendiri. Untuk itu, pemerintah berupaya meningkatkan penerimaan negara dari sektor pajak.

Penghindaran pajak dapat dilakukan dengan Tax planning atau dengan tax avoidance. Penghindaran pajak dapat dilakukan dengan mencari celah-celah perundang-undang pajak. Bahkan, Penghindaran pajak dapat dilakukan dengan cara penggelapan sebagian atau seluruh pajak yang seharusnya terutang kepada negara. Hal itu dapat timbul karena sifat pajak yang tidak memberikan kontraferstasi langsung kepada wajib pajak sehingga sering muncul keengganan wajib pajak dalam memenuhi kewajiban. Oleh karena itu, dibutuhkan suatu mekanisme pengawasan atas sistem self assessment agar tercapai hasil sesuai yang diharapkan.

Pengawasan dapat dilakukan salah satunya dengan pemeriksaan pajak. Pemeriksaan pajak dilakukan untuk menguji kepatuhan pemenuhan kewajiban perpajakan dalam rangka memberikan kepastian hukum, keadilan, dan pembinaan kepada wajib pajak. Wajib pajak yang patuh adalah wajib pajak orang pribadi atau badan terdaftar di Kantor Pelayanan Pajak (KPP) 
dan telah melakukan kewajiban perpajakannya yaitu dengan melunasi dan melaporkan SPT (surat pemberitahuan) Masa dan Tahunan tepat waktu.

Salah satu produk aktivitas pemeriksaan pajak yang dilakukan oleh fiskus adalah diterbitkannya Surat Ketetapan Pajak (SKP). SKP yang mempunyai potensi untuk meningkatan penerimaan pajak adalah Surat Ketetapan Pajak Kurang Bayar (SKPKB). Hal ini dikarenakan SKPKB merupakan salah satu sarana untuk menagih pajak. Pada umumnya wajib pajak akan segera melunasi utang pajaknya tersebut.

Penagihan pajak juga dilakukan sebagai salah satu cara untuk mengoptimalkan penerimaan pajak, yang berfungsi sebagai sarana pencairan tunggakan pajak, meliputi pemberitahuan Surat Teguran, pemberitahuan Surat Paksa, melaksanakan penyitaan, melaksanakan penyanderaan, dan menjual barang yang telah disita berdasarkan ketentuan yang diatur dalam Undang-Undang Nomor 19 Tahun 1997 tentang Penagihan Pajak dengan Surat Paksa sebagaimana telah diubah dengan (Undang-undang Nomor 28 Tahun 2007).

Diupayakan agar setiap wajib pajak mendapatkan giliran untuk diperiksa dalam rangka menguji pemenuhan kewajiban perpajakannya. Jika wajib pajak setelah ditagih pun belum memenuhi kewajiban pajak, maka Kantor Pelayanan Pajak (KPP) berhak menagih dengan Surat Paksa sesuai dengan hukum perpajakan. Dengan efektifnya penagihan pajak akan dapat meningkatkan penerimaan pajak yang diharapkan dapat memberikan kontribusi terhadap pembangunan nasional. Penerimaan pajak dapat ditingkatkan dengan cara memperbaharui kebijakan-kebijakan perpajakan yang lebih memudahkan wajib pajak untuk melakukan kewajiban perpajakan.

\section{TINJAUAN PUSTAKA}

Menurut (Mardiasmo, 2009), efektivitas adalah ukuran berhasil tidaknya suatu organisasi mencapai tujuannya. Apabila suatu organisasi berhasil mencapai tujuan, maka organisasi tersebut dikatakan telah berjalan efektif. Menurut (Mardiasmo, 2016), Pemeriksaan adalah serangkaian kegiatan untuk mencari, mengumpulkan, mengolah data dan/atau keterangan lainnya untuk menguji kepatuhan pemenuhan kewajiban perpajakan dan untuk tujuan lain dalam rangka melaksanakan ketentuan peraturan perundang-undangan perpajakan.

Menurut (Undang-undang Nomor 28 Tahun 2007) Tentang Ketentuan Umum dan Tata Cara Perpajakan, pajak adalah kontribusi wajib kepada Negara yang terhutang oleh orang pribadi atau badan yang bersifat memaksa yang berdasarkan Undang - undang dengan tidak mendapat imbalan secara langsung, dan digunakan untuk keperluan Negara bagi sebesarbesarnya kemakmuran rakyat.

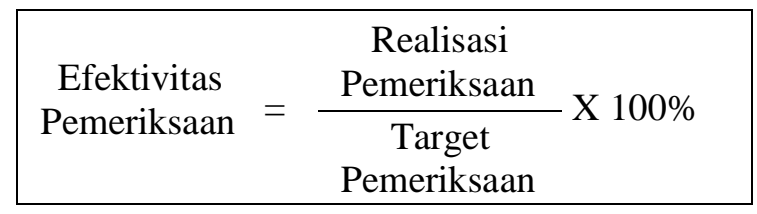

Menurut (Rusjdi, 2007), yaitu surat yang diterbitkan apabila Wajib Pajak tidak melunasi hutang pajaknya sampai dengan tanggal jatuh tempo. Sehingga dapat disimpulkan bahwa surat paksa dikeluarkan atau diterbitkan apabila wajib pajak tidak juga membayar pajak sesuai tanggal jatuh tempo yang telah ditetapkan. Surat paksa ini juga termasuk dalam produk hukum yang eksekutorial yang diterbitkan atas STP. Dalam UU PPSP Pasal 7 ayat (1) dijelaskan bahwa surat paksa berkepala kata-kata "Demi Keadilan berdasarkan Ketuhanan Yang Maha Esa", mempunyai kekuatan eksekutorial dan kedudukan hukum yang sama dengan putusan pengadilan yang telah mempunyai kekuatan hukum tetap. 


\begin{tabular}{|c|c|}
\hline Efektivitas \\
Penagihan
\end{tabular}$=\frac{\begin{array}{c}\text { Surat Paksa } \\
\text { Dibayar }\end{array}}{\begin{array}{c}\text { Surat Paksa } \\
\text { Terbit }\end{array}}$ X 100\%

Menurut (Hutagoal, 2007) Penerimaan Pajak adalah sumber penerimaan yang dapat diperoleh secara terus-menerus dan dapat dikembangkan secara optimal sesuai kebutuhan pemerintah serta kondisi masyarakat.

\begin{tabular}{|c|}
\hline Kontribusi \\
$\begin{array}{c}\text { Penerimaan } \\
\text { Pajak }\end{array}$
\end{tabular} $\begin{aligned} & \text { Pencairan } \\
& \text { Tunggakan } \\
& \text { Penerimaan } \\
& \text { PPh }\end{aligned}$

Agustinus Paseleng, A.T. Poputra, S.J. Tangkuman (2013) melakukan penelitian berjudul Efektivitas Penagihan Pajak dengan Surat Teguran dan Surat Paksa terhadap Penerimaan Pajak Penghasilan pada Kantor Pelayanan Pajak Pratama Manado. Penelitian ini bertujuan untuk mengetahui tingkat efektifitas penagihan pajak dengan surat tehuran dan surat paksa di Kantor Pelayanan Pajak Pratama Manado dalam rangka peningkatan penerimaan pajak penghasilan dan mengetahui seberapa besar kontribusi penagihan pajak dengan surat teguran dan surat paksa terhadap penerimaan pajak penghasilan di Kantor Pelayanan Pajak Pratama Manado.

Christine Stephani Silitonga dan Anna Purwaningsih (2012) melakukan penelitian berjudul Pengaruh Faktor Kepatuhan Formal WP Badan dan Pelaksanaan Pemeriksaan Pajak terhadap Penerimaan Pajak Penghasilan di KPP Pratama Padang. Penelitian ini bertujuan untuk mengetahui apakah penerimaan pajak penghasilan di KPP Padang dipengaruhi oleh faktor kepatuhan formal wajib pajak badan dan faktor pelaksanaan pemeriksaan pajak.

Muniroh (2011) melakukan penelitian berjudul Pengaruh Kepatuhan Wajib Pajak dan Pelaksanaan Pemeriksaan Pajak terhadap Penerimaan Pajak pada Kantor Pelayanan Pajak Pratama. Hasil penelitian ini diharapkan dapat berguna sebagai masukan yang bermanfaat bagi pihak-pihak yang berkepentingan, antara lain: untuk mengetahui pengaruh tingkat kepatuhan wajib pajak dan pelaksanaan pemeriksaan pajak secara parsial terhadap penerimaan pajak penghasilan pasal 25/29 di KPP Pratama Bojonagara Bandung.

H. Muda, S.S. Pangemanan, V.Z. Tirayoh (2015) melakukan penelitian berjudul Penagihan Pajak dengan Surat Teguran dan Surat Paksa Dampaknya terhadap Penerimaan Pajak Pertambahan Nilai pada Kantor Pelayanan Pajak Pratama Bitung. Tujuan penelitian ini adalah untuk mengetahui penagihan pajak dengan surat teguran dan surat paksa dampaknya terhadap penerimaan Pajak Pertambahan Nilai pada Kantor Pelayanan Pajak Pratama Bitung dan seberapa besar kontribusi pencairan tunggakan pajak dengan Surat Teguran dan Surat Paksa terhadap penerimaan Pajak Pertambahan Nilai pada Kantor Pelayanan Pajak Pratama Bitung.

Onoja Miriam Ladi dan Iwarere T. Henry (2015) melakukan penelitian ini menemukan efektivitas pemeriksaan pajak terhadap generasi penerimaan pajak di Servis Inland Federal dan untuk mengetahui hubungan antara pemeriksaan pajak dan generasi penerimaan pajak di Servis Inland Federal.

Hipotesis dapat dirumuskan sebagai berikut:

1. Efektivitas Pemeriksaan Pajak berpengaruh signifikan terhadap Penerimaan Pajak pada Kantor Pelayanan Pajak Pratama Batam Utara.

2. Efektivitas Penagihan Pajak dengan Surat Paksa berpengaruh signifikan terhadap Penerimaan Pajak pada Kantor Pelayanan Pajak Pratama Batam Utara 
3. Efektivitas Pemeriksaan Pajak dan Efektivitas Penagihan Pajak dengan Surat Paksa secara bersama-sama berpengaruh signifikan terhadap Penerimaan Pajak pada Kantor Pelayanan Pajak Pratama Batam Utara.

\section{METODE}

Jenis penelitian ini menggunakan penelitian kuantitatif. sumber data yang digunakan adalah data sekunder yang berasal dari laporan tahunan pada Kantor Pelayanan Pajak Pratama Batam Utara. Dalam penelitian ini digunakan dua variabel independen dan satu variabel dependen. Variabel independen adalah efektivitas pemeriksaan pajak dan efektivitas penagihan pajak dengan surat paksa, serta variabel dependen adalah penerimaan pajak.

Variabel independen adalah variabel yang mempengaruhi atau yang menjadi sebab perubahan atau timbulnya variabel dependen, sedangkan varibel dependen adalah variabel yang dipengaruhi atau yang menjadi akibat, karena adanya variabel independen.

Efektivitas adalah ukuran berhasil tidaknya suatu organisasi mencapai tujuannya.Apabila suatu organisasi berhasil mencapai tujuan, maka organisasi tersebut dikatakan telah berjalan efektif. Hal terpenting yang perlu dicatat adalah bahwa efektivitas tidak menyatakan tentang berapa besar biaya yang telah di keluarkan untuk mencapai tujuan tersebut (Mardiasmo, 2009).

Pemeriksaan adalah serangkaian kegiatan untuk mencari, mengumpulkan, mengolah data dan atau keterangan lainnya untuk menguji kepatuhan pemenuhan kewajiban perpajakan dan untuk tujuan lain dalam rangka melaksanakan ketentuan umum peraturan undang-undang pajak (Mardiasmo, 2016).

Penagihan pajak adalah serangkaian tindakan agar penanggung pajak melunasi utang pajak dan biaya penagihan pajak dengan menegur atau memperingatkan, melaksanakan pelaksanaan penagihan seketika dan sekaligus, memberitahukan surat paksa, mengusulkan pencegahan, melaksanakan penyitaan, melaksanakan penyanderaan, menjual barang yang telah disita (Mardiasmo, 2016).

Penerimaan pajak adalah penghasilan yang diperoleh oleh pemerintah yang bersumber dari pajak rakyat. Tidak hanya sampai pada definisi singkat di atas bahwa dana yang diterima di kas negara tersebut akan dipergunakan untuk pengeluaran pemerintah untuk sebesar-besarnya kemakmuran rakyat, sebagaimana maksud dari tujuan negara yang disepakati oleh para pendiri awal negara ini yaitu menyejahterakan rakyat, menciptakan kemakmuran yang berasaskan kepada keadilan sosial (Suherman, 2011).

Populasi adalah wilayah generalisasi yang terdiri atas objek dan subyek yang mempunyai kualitas dan karakteristik tertentu yang ditetapkan oleh peneliti untuk dipelajari dan kemudian ditarik kesimpulannya (Sugiyono, 2012:80).

Menurut Sugiyono (2012:81) Sampel adalah bagian dari jumlah dan karakteristik yang dimiliki oleh populasi. Sampel yang digunakan peneliti dalam penelitian ini adalah Laporan Kantor Pelayanan Pajak Pratama Batam Utara periode tahun 2011-2015 yaitu 5 sampel.

Dalam pengujian ini teknik pengambilan sampel yang digunakan adalah Teknik sampling jenuh, yaitu mengambil semua data dari populasi yang ada dan pengumpulan data yang digunakan yaitu dengan studi pustaka dan studi dokumentasi.

Metode analisis data dalam penelitian ini adalah: 1. statistik deskriptif adalah statistik yang digunakan untuk menganalisa data dengan cara mendiskripsikan atau menggambarkan data yang telah terkumpul sebagaimana adanya tanpa bermaksud membuat kesimpulan yang berlaku untuk umum atau generalisasi (Sugiyono, 2014), 2. uji asumsi klasik yang terdiri dari uji normalitas, uji multikolinearitas, dan uji heteroskedastisitas.

Uji normalitas bertujuan untuk menguji apakah model regresi, variabel penggangu atau residual memiliki distribusi normal. Uji normalitas dilakukan dengan analisis grafik yaitu dengan melihat grafik histogram dan normal probability plot serta uji statistik non parametrik Kolmogorov-Smirnov (K-S) dengan melihat tingkat signifikansinya (Ghozali, 2011).

Menurut (Ghozali, 2011) uji multikolinieritas bertujuan untuk menguji apakah model regresi ditemukanadanya korelasi antar variabel bebas (independen). Untuk menguji 
multikolinieritas dengan cara melihat nilai VIF masing-masing variabel independen, jika nilai VIF $\leq 10$, maka dapat disimpulkan data bebas dari gejala multikolinieritas.

Uji heterokedastisitas bertujuan menguji apakah dalam model regresi terjadi ketidaksamaan variance dari residual satu pengamatan ke pengamatan yang lain. Ada beberapa cara yang dapat dilakukan untuk melakukan uji heteroskedastisitas, yaitu uji grafik plot, uji park, uji glejser, dan uji white. Pengujian pada penelitian ini menggunakan Grafik Plot antara nilai prediksi variabel dependen yaitu ZPRED dengan residualnya SRESID. Tidak terjadi heteroskedastisitas apabila tidak ada pola yang jelas, serta titik-titik menyebar di atas dan di bawah angka 0 pada sumbu Y (Ghozali, 2011).

Uji autokorelasi bertujuan menguji apakah dalam model regresi linier ada korelasi antara kesalahan pengganggu pada periode $t$ dengan kesalahan pengganggu pada periode $t-1$ (sebelumnya). Jika terjadi korelasi, maka dinamakan ada problem autokorelasi (Ghozali, 2011), Regresi linier berganda merupakan regresi linier di mana sebuah variabel terikat (variabel Y) dihubungkan dengan dua atau lebih variabel bebas (variabel X).

Analisis regresi linier berganda adalah suatu analisis peramalan nilai pengaruh dua atau variabel bebas terhadap variabel terikat untuk membuktikan ada atau tidaknya hubungan fungsi atau hubungan kausal antara dua variabel bebas atau lebih $\left(\mathrm{X}_{1}\right),\left(\mathrm{X}_{2}\right),\left(\mathrm{X}_{3}\right), \ldots(\mathrm{Xn})$ dengan satu variabel terikat.

$$
\mathrm{Y}^{1}=\alpha+\beta_{1} \mathrm{X}_{1}+\beta_{2} \mathrm{X}_{2} \ldots .+\mathrm{e}
$$

Uji hipotesis terdiri dari 3 uji yaitu uji parsial (uji t), uji simultan (uji f), dan uji koefisien determinasi $\left(\mathrm{R}^{2}\right)$, 5. uji parsial adalah untuk mengetahui seberapa jauh pengaruh dari variabel independen (X) terhadap variabel dependen (Y) secara parsial (Ghozali, 2013), 6. Uji F menunjukkan apakah semua variabel independen atau bebas yang dimasukkan dalam model mempunyai pengaruh secara bersama-sama terhadap variabel dependen atau terikat (Ghozali, 2013), 7. Koefisien determinasi $\left(\mathrm{R}^{2}\right)$ pada intinya mengukur seberapa jauh kemampuan model dalam menerangkan variasi variabel dependen.

Lokasi penelitian ini dilakukan di Kantor Pelayan Pajak Pratama Batam Utara, yang beralamat di Jalan Kuda Laut No. 1 Batu Ampar, Batam.

\section{HASIL DAN PEMBAHASAN}

Tabel 1 Hasil Uji Statistik Deskriptif

Hasil Uji Statistik Deskriptif

Descriptive Statistics

\begin{tabular}{|l|c|c|c|c|c|}
\hline & N & Minimum & Maximum & Mean & Std. Deviation \\
\hline KontribusiPenerimaanPajak & 5 & 1.369 & 1.955 & 1.64795 & .210524 \\
EfektivitasPemeriksaanPajak & 5 & 11.085 & 66.921 & 27.73507 & 22.388698 \\
EfektivitasPenagihanPajakDenganSu & 5 & 25.571 & 63.475 & 50.74186 & 14.724658 \\
ratPaksa & & & & & \\
Valid N (listwise) & 5 & & & & \\
\hline
\end{tabular}

Berdasarkan Tabel 1 Hasil Uji Statistik Deskriptif menunjukan penerimaan pajak mempunyai nilai minimum1,369, nilai maksimum 1,955, mean 1,64795 dan standar deviasi 0,210524 . Efektivitas pemeriksaan pajak mempunyai nilai minimum 11,085, nilai maksimum 66,921, mean 27,73507 dan standar deviasi 22,388698. Efektivitas penagihan pajak dengan surat paksa mempunyai nilai minimum 25,571, nilai maksimum 63,475, mean 50,74186 dan standar deviasi 14,724658. 


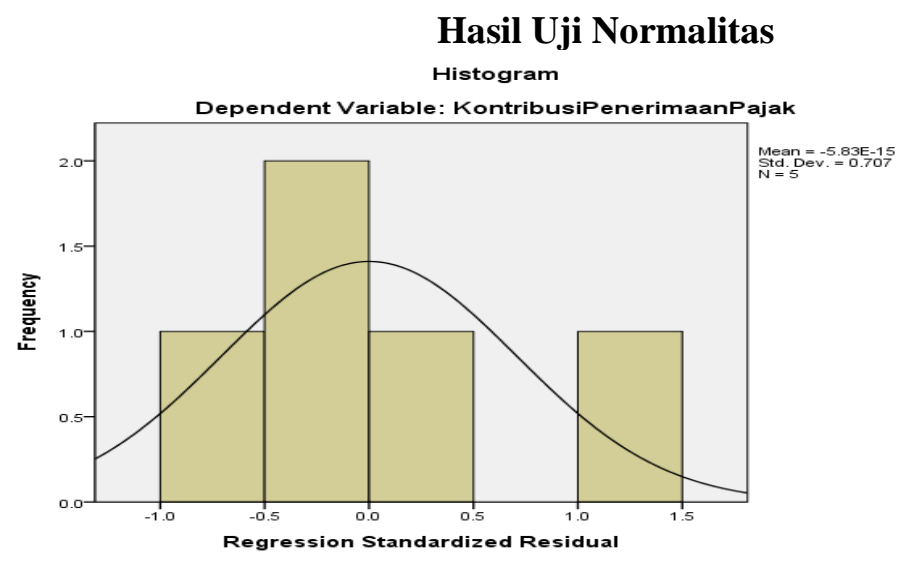

Gambar 1 Hasil Uji Normalitas - Grafik Histogram

Berdasarkan Gambar 1 grafik histrogram di atas terlihat bahwa data menyebar dari kiri ke kanan, dan berbentuk lonceng maka data dinyatakan memenuhi asumsi normalitas atau data berdistribusi normal.

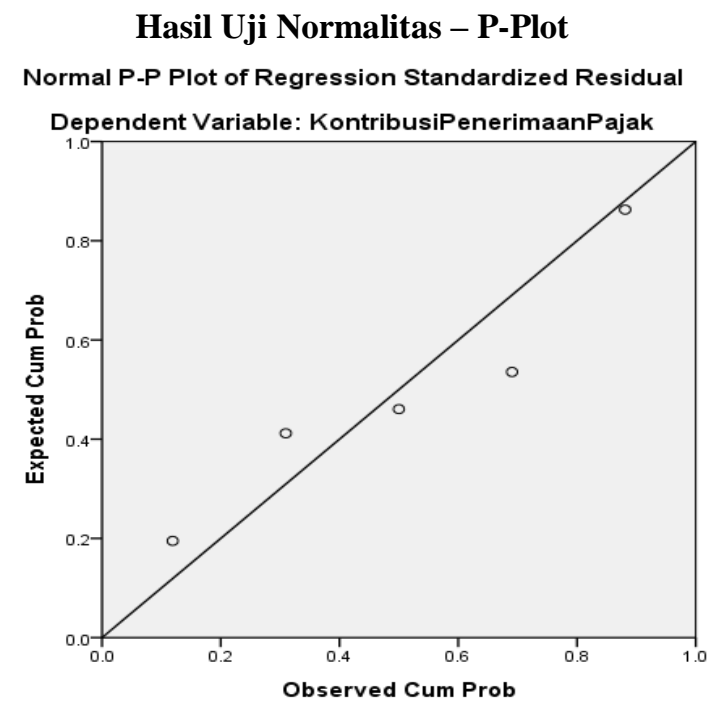

Gambar 2 Hasil Uji Normalitas - P-Plot

Berdasarkan Gambar 2 grafik Normal P-P Plot terlihat bahwa titik-titik menyebar di sekitar garis diagonal dan penyebarannya mengikuti arah garis diagonal. Dari grafik ini dapat disimpulkan bahwa model garis regresi memenuhi asumsi normalitas.

Tabel 2 Hasil Uji Kolmogorv-Smirnov

Hasil Uji Kolmogorv-Smirnov

One-Sample Kolmogorov-Smirnov Test

\begin{tabular}{|ll|r|}
\hline & & \multicolumn{1}{|c|}{ Unstandardized Residual } \\
\hline $\mathrm{N}$ & & 5 \\
Normal Parameters & Mean & .0000000 \\
& Std. Deviation & .01067886 \\
& Absolute & .250 \\
Most Extreme Differences & Positive & .250 \\
& Negative & -.176 \\
Kolmogorov-Smirnov Z & & .559 \\
Asymp. Sig. (2-tailed) & & .914 \\
\hline
\end{tabular}

a. Test distribution is Normal.

b. Calculated from data. 
Berdasarkan Tabel 2 hasil uji kolmogorov-smirnov diambil kesimpulan bahwa nilai Kolmogrov-Smirnov memiliki tingkat signifikansi 0,914 > 0,05, sehingga dapat disimpulkan bahwa data berdistribusi normal.

Tabel 3 Hasil Uji Multikolienaritas Hasil Uji Multikolinearitas Coefficients $^{\mathrm{a}}$

\begin{tabular}{|c|c|c|c|c|c|c|}
\hline \multirow[t]{2}{*}{ Model } & & \multicolumn{2}{|c|}{$\begin{array}{l}\text { Unstandardized } \\
\text { Coefficients }\end{array}$} & \multirow{2}{*}{$\begin{array}{c}\begin{array}{l}\text { Standardized } \\
\text { Coefficients }\end{array} \\
\text { Beta }\end{array}$} & \multicolumn{2}{|c|}{ Collinearity Statistics } \\
\hline & & $\mathrm{B}$ & $\begin{array}{l}\text { Std. } \\
\text { Error }\end{array}$ & & Tolerance & VIF \\
\hline \multirow{3}{*}{1} & (Constant) & 1.132 & .027 & & & \\
\hline & EfektivitasPemeriksaanPajak & .007 & .000 & .702 & .793 & 1.261 \\
\hline & $\begin{array}{l}\text { EfektivitasPenagihanPajakDenganSu } \\
\text { ratPaksa }\end{array}$ & .007 & .001 & .459 & .793 & 1.261 \\
\hline
\end{tabular}

a. Dependent Variable: KontribusiPenerimaanPajak

Berdasarkan tabel 3 diatas hasil uji multikolinearitas menunjukkan bahwa dua variabel indenpenden yaitu efektivitas pemeriksaan pajak memiliki nilai sebesar 1,261 dan efektivitas penagihan pajak dengan surat paksa memiliki nilai sebesar 1,260. Nilai VIF untuk variabel indenpenden lebih kecil dari 10. Sehingga dapat disimpulkan bahwa ketiga variabel indenpenden tidak terjadi multikolinearitas.

\section{Hasil Uji Heteroskedastisitas}

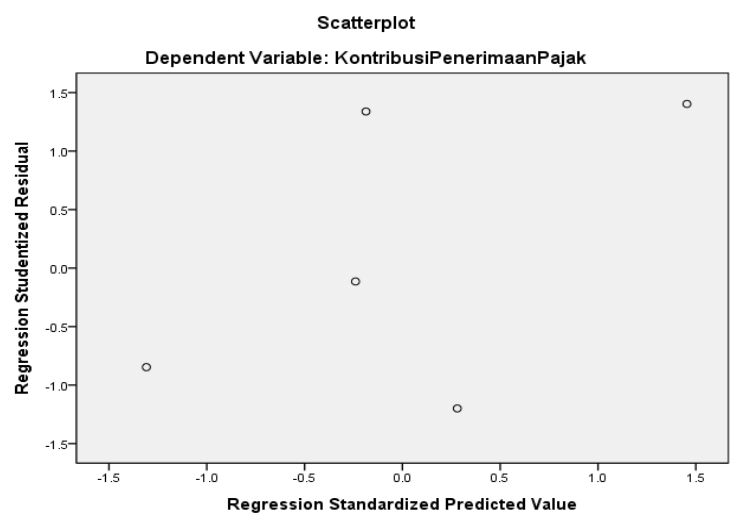

Gambar 3 Hasil Uji Heteroskedastisitas

Berdasarkan Gambar 3 di atas, hasil uji heteroskedastisitas menunjukkan titik-titik menyebar secara acak serta tersebar baik di atas maupun di bawah angka 0 (nol) pada sumbu Y. jadi dapat disimpulkan bahwa model regresi tidak mengandung adanya heteroskedastisitas.

Tabel 4 Hasil Uji Heteroskedastisitas

Coefficients $^{\mathrm{a}}$

\begin{tabular}{|ll|c|c|c|c|c|}
\hline Model & \multicolumn{2}{|c|}{$\begin{array}{c}\text { Unstandardized } \\
\text { Coefficients }\end{array}$} & $\begin{array}{c}\text { Standardized } \\
\text { Coefficients }\end{array}$ & \multirow{2}{*}{$\mathrm{t}$} & \multirow{2}{*}{ Sig. } \\
\cline { 3 - 5 } & & $\mathrm{B}$ & $\begin{array}{c}\text { Std. } \\
\text { Error }\end{array}$ & Beta & & \\
\hline \multirow{2}{*}{1} & (Constant) & $-1.001 \mathrm{E}-013$ & .027 & & .000 & 1.000 \\
& EfektivitasPemeriksaanPajak & .000 & .000 & .000 & .000 & 1.000 \\
& EfektivitasPenagihanPajakDenga & .000 & .001 & .000 & .000 & 1.000 \\
& nSuratPaksa & & & & & \\
\hline
\end{tabular}

a. Dependent Variable: Abresid 
Berdasarkan Tabel 4 di atas menunjukkan bahwa nilai signifikansi kedua variabel independen lebih dari 0,05. Dengan demikian dapat disimpulkan bahwa model regresi tidak mengandung adanya heteroskedastisitas

Tabel 5 Hasil Uji Analisis Autokorelasi

Hasil Uji Analisis Autokorelasi

Model Summary ${ }^{\mathrm{b}}$

\begin{tabular}{|c|c|c|c|c|c|}
\hline Model & $\mathrm{R}$ & $\mathrm{R}$ Square & Adjusted R Square & $\begin{array}{c}\text { Std. Error of the } \\
\text { Estimate }\end{array}$ & Durbin-Watson \\
\hline 1 & $.999^{\mathrm{a}}$ & .997 & .995 & .015102 & 1.371 \\
\hline
\end{tabular}

a. Predictors: (Constant), EfektivitasPenagihanPajakDenganSuratPaksa, EfektivitasPemeriksaanPajak

b. Dependent Variable: KontribusiPenerimaanPajak

Berdasarkan tabel diatas, diketahui nilai Durbin-Watson sebesar 1,298 yang berada diantara -2 smpai 2 atau $-2<1,371<+2$ sehingga dapat disimpulkan model regresi berganda tersebut tidak terjadi autokorelasi

Tabel 6 Hasil Uji Analisis Regresi Linier Berganda

Hasil Uji Analisis Regresi Linier Berganda Coefficients $^{\mathrm{a}}$

\begin{tabular}{|c|c|c|c|c|c|c|}
\hline \multirow{2}{*}{\multicolumn{2}{|c|}{ Model }} & \multicolumn{2}{|c|}{$\begin{array}{c}\text { Unstandardized } \\
\text { Coefficients }\end{array}$} & $\begin{array}{l}\text { Standardized } \\
\text { Coefficients }\end{array}$ & \multirow[t]{2}{*}{$\mathrm{T}$} & \multirow[t]{2}{*}{ Sig. } \\
\hline & & $\mathrm{B}$ & $\begin{array}{c}\text { Std. } \\
\text { Error }\end{array}$ & Beta & & \\
\hline \multirow{3}{*}{1} & (Constant) & 1.132 & .027 & & 41.869 & .001 \\
\hline & EfektivitasPemeriksaanPajak & .007 & .000 & .702 & 17.429 & .003 \\
\hline & $\begin{array}{l}\text { EfektivitasPenagihanPajakDe } \\
\text { nganSuratPaksa }\end{array}$ & .007 & .001 & .459 & 11.401 & .008 \\
\hline
\end{tabular}

Berdasarkan hasil pengolahan data pada Tabel 6 hasil uji analisis regresi linier berganda dapat diperoleh persamaan regresi sebagai berikut:

$$
\mathrm{Y}^{1}=\alpha+\beta_{1} \mathrm{X}_{1}+\beta_{2} \mathrm{X}_{2} \ldots \ldots+\mathrm{e}
$$

Artinya :

1. Konstanta memiliki nilai konstan sebesar 1,132 ini menunjukkan jika X1 (Efektivitas Pemeriksaan Pajak) dan X2 (Efektivitas Penagihan Pajak dengan Surat Paksa) nilai adalah nol, maka Y (Pemeriksaan Pajak) memiliki nilai 1.132.

2. Variabel X1 (Efektivitas Pemeriksaan Pajak) memiliki nilai koefisien regresi sebesar 0,007 ini berarti jika variabel indenpenden menunjukkan kenaikan efektivitas pemeriksaan pajak, maka setiap kenaikan 1 poin atau $1 \%$ variabel X1 (Efektivitas Pemeriksaan Pajak) akan meningkatkan nilai Y (Pemeriksaan Pajak) sebesar 0,007.

3. Variabel X2 (Efektivitas Penagihan Pajak dengan Surat Paksa) memiliki nilai koefisien regresi sebesar 0,007 ini berarti jika variabel indenpenden menunjukkan kenaikan efektivitas penagihan pajak dengan surat paksa, maka setiap keturunan 1 poin atau $1 \%$ X2 (Efektivitas Penagihan Pajak dengan Surat Paksa) akan menurunkan nilai Y (Pemeriksaan Pajak) sebesar 0,007. 
Tabel 7 Hasil Uji $\mathrm{t}$

Coefficients $^{\mathrm{a}}$

\begin{tabular}{|c|c|c|c|c|c|c|}
\hline \multirow{2}{*}{\multicolumn{2}{|c|}{ Model }} & \multicolumn{2}{|c|}{$\begin{array}{c}\text { Unstandardized } \\
\text { Coefficients }\end{array}$} & $\begin{array}{c}\text { Standardized } \\
\text { Coefficients }\end{array}$ & \multirow[t]{2}{*}{$\mathrm{t}$} & \multirow[t]{2}{*}{ Sig. } \\
\hline & & $\mathrm{B}$ & Std. Error & Beta & & \\
\hline \multirow{3}{*}{1} & (Constant) & 1.132 & .027 & & 41.869 & .001 \\
\hline & EfektivitasPemeriksaanPajak & .007 & .000 & .702 & 17.429 & .003 \\
\hline & $\begin{array}{l}\text { EfektivitasPenagihanPajakDe } \\
\text { nganSuratPaksa }\end{array}$ & .007 & .001 & .459 & 11.401 & .008 \\
\hline
\end{tabular}

Berdasarkan Tabel 7 hasil uji t (Parsial) diperoleh bahwa Efektivitas Pemeriksaan Pajak (X1) secara parsial berpengaruh signifikan terhadap Penerimaan Pajak (Y) dan Efektivitas Penagihan Pajak dengan Surat Paksa (X2) secara parsial berpengaruh signifikan terhadap Penerimaan Pajak (Y) dengan taraf signifikan masing-masing variabel (X1) 0,003 dan variabel (X2) $0,008<0,005$.

Tabel 8 Hasil Uji F

ANOVA

\begin{tabular}{|ll|c|c|c|c|c|}
\hline Model & & Sum of Squares & Df & Mean Square & F & Sig. \\
\hline \multirow{3}{*}{1} & Regression & .177 & 2 & .088 & 387.645 & $.003^{\mathrm{b}}$ \\
& Residual & .000 & 2 & .000 & & \\
& Total & .177 & 4 & & & \\
\hline
\end{tabular}

a. Dependent Variable: KontribusiPenerimaanPajak

b.Predictors:(Constant),EfektivitasPenagihanPajakDenganSuratPaksa,EfektivitasPemeriksaanPajak

Berdasarkan Tabel 8 hasil Uji F (Simultan) diperoleh tingkat signifikan adalah 0,003 < 0,005 dan nilai F 387,645 maka dapat disimpulkan bahwa Efektivitas Pemeriksaan Pajak (X1) dan Efektivitas Penagihan Pajak dengan Surat Paksa (X2) secara simultan/bersama-sama berpengaruh signifikan terhadap Penerimaan Pajak (Y).

Tabel 9 Hasil Uji Analisis Koefisien Determinasi $\left(\mathrm{R}^{2}\right)$ Model Summary ${ }^{\text {b }}$

\begin{tabular}{|c|c|c|c|c|c|}
\hline Model & $\mathrm{R}$ & R Square & $\begin{array}{c}\text { Adjusted R } \\
\text { Square }\end{array}$ & $\begin{array}{c}\text { Std. Error of the } \\
\text { Estimate }\end{array}$ & Durbin-Watson \\
\hline 1 & $.999^{\mathrm{a}}$ & .997 & .995 & .015102 & 1.371 \\
\hline
\end{tabular}

a. Predictors: (Constant), EfektivitasPenagihanPajakDenganSuratPaksa, EfektivitasPemeriksaanPajak

Dependent Variable: KontribusiPenerimaanPajak

Berdasarkan tabel 9 di atas menunjukkan besarnya nilai koefisien determinasi ( $\mathrm{R}$ Square) adalah 0,997. Hal ini berarti 99,7\% . nilai ini menunjukkan bahwa variabel penerimaan pajak dapat dijelaskan atau dipengaruhi $99,7 \%$ oleh efektivitas pemeriksaan pajak dan efektivitas penagihan pajak dengan surat paksa. sedangkan sisanya $0,3 \%$ dijelaskan atau dipengaruhi oleh faktor-faktor lain yang tidak dijelaskan dalam model penelitian ini.

\section{Pembahasan}

Pengaruh Efektivitas Pemeriksaan Pajak Terhadap Penerimaan Pajak: Berdasarkan hasil penelitian yang diteliti dengan menggunakan SPSS versi 21. Diketahui hasil uji t pada variabel efektivitas pemeriksaan pajak menunjukkan nilai $t_{\text {hitung }} 17.429$ dan signifikansi sebesar 0.003. Nilai ini menunjukkan bahwa $\mathrm{t}_{\text {hitung }}>$ dari $\mathrm{t}_{\text {tabel }} 2,015$ atau signifikansi lebih kecil dari 0,05

Pengaruh Efektivitas Penagihan Pajak Dengan Surat Paksa Terhadap Penerimaan Pajak: Berdasarkan hasil penelitian yang diteliti dengan menggunakan SPSS versi 21. Diketahui hasil uji $t$ pada variabel efektivitas penagihan pajak dengan surat paksa menunjukkan nilai $t_{\text {hitung }}$ 11.401 dan signifikansi sebesar 0.008. Nilai ini menunjukkan bahwa $t_{\text {hitung }}>$ dari $t_{\text {tabel }} 2,015$ atau signifikansi lebih kecil dari 0,05 
Pengaruh Efektivitas Pemeriksaan Pajak dan Efektivitas Penagihan Pajak Dengan Surat Paksa Terhadap Penerimaan Pajak: Hasil pengujian mengenai pengaruh efektivitas pemeriksaan pajak dan efektivitas pajak dengan surat paksa terhadap penerimaan pajak menunjukkan nilai $\mathrm{F}$ hitung sebesar 387,645 dengan df pembilang $=2$ dan df penyebut $=2$ dan tarif signifikasi sebesar 0,03 lebih kecil dengan tarif signifikansi 0,05 maka Ho ditolak dan Ha diterima sehingga dapat disimpulkan bahwa variabel efektivitas pemeriksaan pajak dan efektivitas penagihan pajak dengan surat paksa secara simultan berpengaruh signifikan terhadap penerimaan pajak.

\section{SIMPULAN}

Berdasarkan hasil analisis data dengan menggunakan analisis regresi data linier berganda, maka dapat diambil kesimpulan sebagai berikut:

1. Variabel Efektivitas Pemeriksaan Pajak $\left(\mathrm{X}_{1}\right)$ berpengaruh signifikan secara parsial terhadap penerimaan pajak (Y). Hipotesis dalam penelitian ini di terima.

2. Variabel Efektivitas Penagihan Pajak Dengan Surat Paksa $\left(\mathrm{X}_{2}\right)$ berpengaruh signifikan secara parsial terhadap variabel Penerimaan Pajak (Y). Hipotesis dalam penelitian ini di terima

3. (3) Variabel Efektivitas Pemeriksaan Pajak dan Efektivitas Penagihan Pajak Dengan Surat Paksa berpengaruh signifikan secara simultan terhadap variabel Pemeriksaan Pajak.

4. Hasil analisis menunjukkan besarnya nilai koefisien determinasi ( $R$ Square) adalah 0,997. Hal ini berarti ada 99,7\% yang menunjukkan bahwa variabel efektivitas pemeriksaan pajak dan efektivitas penagihan pajak dengan surat paksa sangat berpengaruh sedangkan sisanya $0,3 \%$ dijelaskan atau dipengaruhi oleh faktor-faktor lain yang tidak dijelaskan dalam model penelitian ini.

\section{DAFTAR PUSTAKA}

Chritine Stephani Silitonga Dan Anna Purwaningsih. (2012). Pengaruh Faktor Kepatuhan Formal Wp Badan Dan Pelaksaan Pemeriksaan Pajak Terhadap Penerimaan Pajak Terhadap Penerimaan Pajak Penghasilan Di Kpp Pratama Padang, 24 (1)(0852-1875).

Ghozali, I. (2013). Aplikasi Analisis Mulitivariate Dengan Program Ibm Spss 21. Semarang.

Hazra Muda, D. (2015). Penagihan Pajak Dengan Surat Paksa Teguran Dan Surat Paksa Dampaknya Terhadap Penerimaan Pajak Pertambahan Nilai Pada Kantor Pelayanan Pajak Pratama Bitung, 3(4), 1-12.

Mardiasmo. (2011). Perpajakan. Yogyakarta: Andi.

Mardiasmo. (2016). Perpajakan (8th Ed.). Yogyakarta: Andi.

Murinoh. (2011). Pengaruh Kepatuhan Wajib Pajak Dan Pelaksanaan Pemeriksaan Pajak Terhadap Penerimaan Pajak Pada Kantor Pelayanan Pajak Pratama, (342).

Onoja M.L Dan Iwarere T.Henry (2015) Journal Of Good Governance And Sustainable

Development In Africa (Jggsda), Vol. 2 No 4 May, 2015. Issn:2346-72x

Pajak, D. J. (N.D.-A). Peraturan Menteri Keuangan Nomor 17/Pmk.03/2013.

Pajak, D. J. (N.D.-B). Surat Edaran-10/Pj .04/2008.

Paselang.A. (2013). Efektivitas Penagihan Pajak Dengan Surat Teguran Dan Surat Paksa Terhadap Penerimaan Pajak Penghasilan Pada Kantor Pelayanan Pajak Pratama Manado, 1(4), 2371-2381.

Republik, I. (N.D.). Undang-Undang 1945 Pasal 23 Ayat 2.

Republik, I. (N.D.). Undang-Undang Nomor 19 Tahun 1997 Tentang Penagihan Pajak Dengan Surat Pajak Sebagaimana Telah Diubah Dengan Undang-Undang Nomor 19 Tahun 2000.

Republik, I. (N.D.). Undang-Undang Nomor 28 Tahun 2007 Tentang Ketentuan Umum Dan Tata Cara Perpajakan.

Republik, I. (N.D.). Undang-Undang Nomor 28 Tahun 2007 Tentang Perubahan Ketiga Undang-Undang Nomor 6 Tahun 1983 Tentang Ketentuan Umum Dan Tata Cara Perpajakan. 
Republik, I. (N.D.). Uu No.19/2000 Pasal 01 Angka 9 Tentang Penagihan Pajak Dengan Surat Paksa.

Sugiyono. (2012). Metode Penelitian Kuantitatif Kualitatif Dan R\&D. Bandung, Alfabeta.

Sugiyono. (2014). Metode Penelitian Kuantitatif Kualitatif Dan R\&D. Bandung, Alfabeta.

Sugiyono. (2015). Bandung, Alfabeta. Bandung, Alfabeta.

Sujarweni. (2015). Metodologi Penelitian Bisnis Ekonomi. Pustaka Baru.

Sukirman. (2011). Pengaruh Pemeriksaan Pajak Terhadap Penerimaan Pajak ( Studi Kasus: Di Kpp Semarang Timur ), 5(1), 87-101.

Sunyoto, D. (2012a). Manajemen Sumber Daya Manusia (Cetakan Pe). Yogyakarta.

Sunyoto, D. (2012b). Teori, Kuesioner Dan Analisis Data Sumber Daya Manusia (Praktik Penelitian) (Cetakan Pe). Yogyakarta.

Wibowo. (N.D.). Aplikasi Praktis Spss Dalam Penelitian Penerbit Gava Media. Yogyakarta. 